\title{
Case Report: Neonatal Diabetes Mellitus Caused by a Novel GLIS3 Mutation in Twins
}

\section{OPEN ACCESS}

Edited by:

Valentino Cherubini,

Azienda Ospedaliero Universitaria

Ospedali Riuniti, Italy

Reviewed by:

Fabrizio Barbetti,

University of Rome Tor Vergata, Italy Katja Dumic Kubat,

University of Zagreb, Croatia

*Correspondence:

Yardena Tenenbaum-Rakover

Rakover_y@clalit.org.il

${ }^{\dagger}$ These authors have contributed equally to this work

Specialty section:

This article was submitted to Pediatric Endocrinology,

a section of the journal

Frontiers in Endocrinology

Received: 28 February 2021 Accepted: 29 April 2021 Published: 18 May 2021

Citation:

London S, De Franco E

Elias-Assad G, Barhoum MN,

Felszer C, Paniakov M, Weiner SA and

Tenenbaum-Rakover Y (2021)

Case Report: Neonatal Diabetes

Mellitus Caused by a Novel

GLIS3 Mutation in Twins.

Front. Endocrinol. 12:673755.

doi: 10.3389/fendo.2021.673755

\begin{abstract}
Shira London ${ }^{1 \dagger}$, Elisa De Franco ${ }^{2 \dagger}$, Ghadir Elias-Assad ${ }^{1,3}$, Marie Noufi Barhoum ${ }^{1,4,5}$, Clari Felszer ${ }^{6}$, Marina Paniakov ${ }^{6}$, Scott A. Weiner ${ }^{6}$ and Yardena Tenenbaum-Rakover ${ }^{1,3 *}$

1 Pediatric Endocrine Institute, Ha'Emek Medical Center, Afula, Israel, 2 Institute of Biomedical and Clinical Science, College of Medicine and Health, University of Exeter, Exeter, United Kingdom, ${ }^{3}$ The Rappaport Faculty of Medicine, Technion - Institute of Technology, Haifa, Israel, ${ }^{4}$ Clalit Health Services, Children Health Center, Naharia, Israel, ${ }^{5}$ Faculty of Medicine, Bar-llan University, Zeffat, Israel, 6 Neonatal Intensive Care Unit, Ha'Emek Medical Center, Afula, Israel
\end{abstract}

Background: Mutations in GLIS3 cause a rare syndrome characterized by neonatal diabetes mellitus (NDM), congenital hypothyroidism, congenital glaucoma and cystic kidneys. To date, 14 mutations in GLIS3 have been reported, inherited in an autosomal recessive manner. GLIS3 is a key transcription factor involved in $\beta$-cell development, insulin expression, and development of the thyroid, eyes, liver and kidneys.

Cases: We describe non-identical twins born to consanguineous parents presenting with NDM, congenital hypothyroidism, congenital glaucoma, hepatic cholestasis, cystic kidney and delayed psychomotor development. Sequence analysis of GLIS3 identified a novel homozygous nonsense mutation, c.2392C>T, p.GIn798Ter (p.Q798*), which results in an early stop codon. The diabetes was treated with a continuous subcutaneous insulin infusion pump and continuous glucose monitoring. Fluctuating blood glucose and intermittent hypoglycemia were observed on follow-up.

Conclusions: This report highlights the importance of early molecular diagnosis for appropriate management of NDM. We describe a novel nonsense mutation of GLIS3 causing NDM, extend the phenotype, and discuss the challenges in clinical management. Our findings provide new areas for further investigation into the roles of GLIS3 in the pathophysiology of diabetes mellitus.

Keywords: $\beta$-cell development, congenital glaucoma, congenital hypothyroidism, GLIS3 mutation, neonatal diabetes

\section{INTRODUCTION}

Neonatal diabetes mellitus (NDM) diagnosed before 6 months of age is a rare monogenic condition occurring in 1:100,000 live births in Europe $(1,2)$, and 1:30,000 (3-fold higher) in the Middle East $(3,4)$. The incidence of permanent NDM in the Middle East is even higher (10-fold) $(1,4)$. NDM accounts for 1:4000 cases of diabetes in children $(5,6)$. It may be either isolated or associated with multiorgan involvement. Genetic mutations causing NDM result in impaired insulin function due to one of the following mechanisms: abnormal pancreatic development, abnormal $\beta$-cell function or 
$\beta$-cell destruction. Mutations in over 25 genes have been reported to cause NDM (7-9), with syndromic NDM accounting for over $10 \%$ of the cases (9).

GLIS3 encodes the zinc finger protein GLI-similar protein 3 (GLIS3), a transcription factor expressed in the developing pancreas and involved in the development of the thyroid, eyes, liver and kidneys (10-14). GLIS3 can function as a repressor or activator, playing critical roles in the regulation of various cellular processes $(15,16)$. In the pancreas, GLIS3 is expressed at various stages of ductal and endocrine cell development, regulating $\beta$-cell development and insulin expression (12). Mutations in GLIS3 (OMIM 610192) were described in 2006 as the cause of a rare syndrome characterized by NDM, congenital hypothyroidism $(\mathrm{CH})$ and congenital glaucoma $(\mathrm{CG})(17,18)$. Other features included intrauterine growth retardation (IUGR), cystic renal disease and hepatic cholestasis or fibrosis. In addition, developmental delay, facial dysmorphism, skeletal abnormalities and exocrine pancreatic dysfunction have been described $(4,17-$ 22). To date, 14 GLIS3 mutations have been reported (http://www. hgmd.cf.ac.uk/ac/gene.php) (4, 17, 20-22).

Herein, we report on two non-identical twins presenting with NDM, CG and $\mathrm{CH}$ caused by a novel homozygous GLIS3 mutation. This case report expands our knowledge of the clinical phenotype, management approaches and outcome of infants with GLIS3 mutations, indicating the need for additional research to further our understanding of the roles of GLIS3.

\section{CASE REPORTS}

\section{Case 1}

The proband was the firstborn male from an IVF dichorionic twin pregnancy born by spontaneous vaginal delivery at 37 weeks gestational age weighing $1984 \mathrm{~g}(-2.53 \mathrm{SDS})$ to healthy consanguineous parents (first cousins) of Arab-Muslim origin. No family history of diabetes was reported in the extended family. The newborn was admitted to the neonatal intensive care unit (NICU) due to low birth weight. In the first $24 \mathrm{~h}$, he had low blood pressure that was treated with intravenous glucose $10 \%$. On examination, no dysmorphic features were observed. Elevated blood glucose levels were observed during the first $24 \mathrm{~h}$ of life and through the first 5 days of life (range 61-443 mg/dL). The patient was treated with total parenteral nutrition for the first 4 days and was switched to milk formula at 5 days of age. He was treated intravenously with regular insulin from day 5 of life at a daily dose of $0.24-1.2 \mathrm{U} / \mathrm{kg}$, which was replaced by a combination of subcutaneously injected diluted Humalog $^{\circledR}$ (insulin lispro) twice daily at a dose of $0.03-0.05 \mathrm{U}$ before meals, and NPH insulin once or twice daily at a dose of $0.2-$ $0.4 \mathrm{U} / \mathrm{kg}$. Due to labile blood glucose levels, treatment with a continuous subcutaneous insulin infusion (CSII) pump (MiniMed 640G SmartGuard ${ }^{\mathrm{TM}}$ system) was initiated at 2 weeks of age. The infant weighed 1730 g. A MMT399 QuickSet Infusion Set was inserted into the upper lateral part of the buttocks. Regular insulin was administered at a basal rate of $0.3-0.6 \mathrm{U} / \mathrm{kg}$ per day with 2-3 boluses of $0.025 \mathrm{U}$ each. The SmartGuard system offers protection against hypoglycemia by automatically stopping insulin instillation when the glucose sensor approaches a predefined lower limit. Maintaining stable blood glucose levels was very challenging due to fluctuating hyperglycemia and hypoglycemia (glucose levels ranged between 50 and $500 \mathrm{mg} / \mathrm{dL}$ ). Hypoglycemic episodes were noted even after a few hours of insulin withdrawal, whereas low insulin-delivery rates resulted in pump obstruction, causing hyperglycemia. CSII using Humalog diluted 1:10 (10 U/mL) with continuous glucose monitoring (CGM) maintained blood glucose within 100-250 mg/dL, but the pump frequently shut down due to decreasing sensor glucose levels, on some days for more than $6 \mathrm{~h}$ (Figure 1). Laboratory assessment revealed very low levels of insulin (less than $0.2 \mu \mathrm{IU} / \mathrm{mL}$; normal range 3.0-25.0), $0.1 \mathrm{ng} / \mathrm{mL}$ C-peptide (normal range 1.1-5.0) and negative anti-pancreatic antibodies (Table 1).

Thyroid function testing during the first week of life revealed primary $\mathrm{CH}$ with thyroid-stimulating hormone (TSH) above 150 $\mu \mathrm{IU} / \mathrm{mL}$ (normal range 0.64-6.27), free thyroxine $\left(\mathrm{FT}_{4}\right)$ less than $1.3 \mathrm{pmol} / \mathrm{L}$ (normal range 11.4-19.0) and free triiodothyronine of $1.99 \mathrm{pmol} / \mathrm{L}$ (normal range 3.5-6.5). Thyroxine (L- $\left.\mathrm{T}_{4}\right)$ therapy was started at a dose of $15 \mu \mathrm{g} / \mathrm{kg}$ per day, which maintained thyroid function within the normal range after 2 weeks. During the follow-up period, his $\mathrm{FT}_{4}$ and $\mathrm{TSH}$ levels were within normal ranges or slightly elevated. Thyroid sonography demonstrated a normally sized non-ectopic thyroid gland.

Corneal opacity was noted early in the course of neonatal care and bilateral CG was diagnosed. Bilateral eye trabeculotomy was performed at 6 weeks of age. Repeat eye surgery was performed at 18 months of age due to increased intraocular pressure.

Renal sonography showed normally sized echogenic kidneys with small cortical cysts, mainly around the pyramids. Blood pressure and renal function tests were normal. Repeated renal sonography at the age of 3 years showed normally sized kidneys with small echogenic foci and small $4 \mathrm{~mm}$ cysts.

The baby developed transient jaundice with mildly elevated liver enzymes during the first days of life: glutamic oxaloacetic transaminase (GOT), $87 \mathrm{U} / \mathrm{L}$ (normal range 0-35); gammaglutamyl transferase (GGT), $247 \mathrm{U} / \mathrm{L}$ (normal range 3-22); and alkaline phosphatase, $555 \mathrm{U} / \mathrm{L}$ (normal range 160-381). Total bilirubin was $6.26 \mathrm{mg} / \mathrm{dL}$ (normal range 0.3-1.2) with direct bilirubin of $0.69 \mathrm{mg} / \mathrm{dL}$ (normal range $0.1-0.3$ ). The liver enzymes completely normalized on follow-up testing and abdominal ultrasonography was unremarkable, demonstrating normal size and texture of the liver, spleen, gallbladder and pancreas. Stool elastase was $396 \mu \mathrm{g} / \mathrm{g}$ (normal range >200), excluding exocrine pancreas insufficiency.

He was readmitted at 4 months and again at 9 months due to viral infection and pneumonia (respectively). During these hospitalizations, his insulin requirements increased 3- to 4fold. At the age of 2.4 years, he was admitted to the ICU for prolonged severe hypoglycemia which occurred during an acute gastroenteritis episode (when he was off the insulin pump for 3 days). Hypoglycemia persisted despite three intramuscular injections of $1 \mathrm{mg}$ glucagon administered by the parents and stabilized only after intravenous administration of glucose in the ICU. Adrenocorticotropin-stimulation test excluded adrenal 

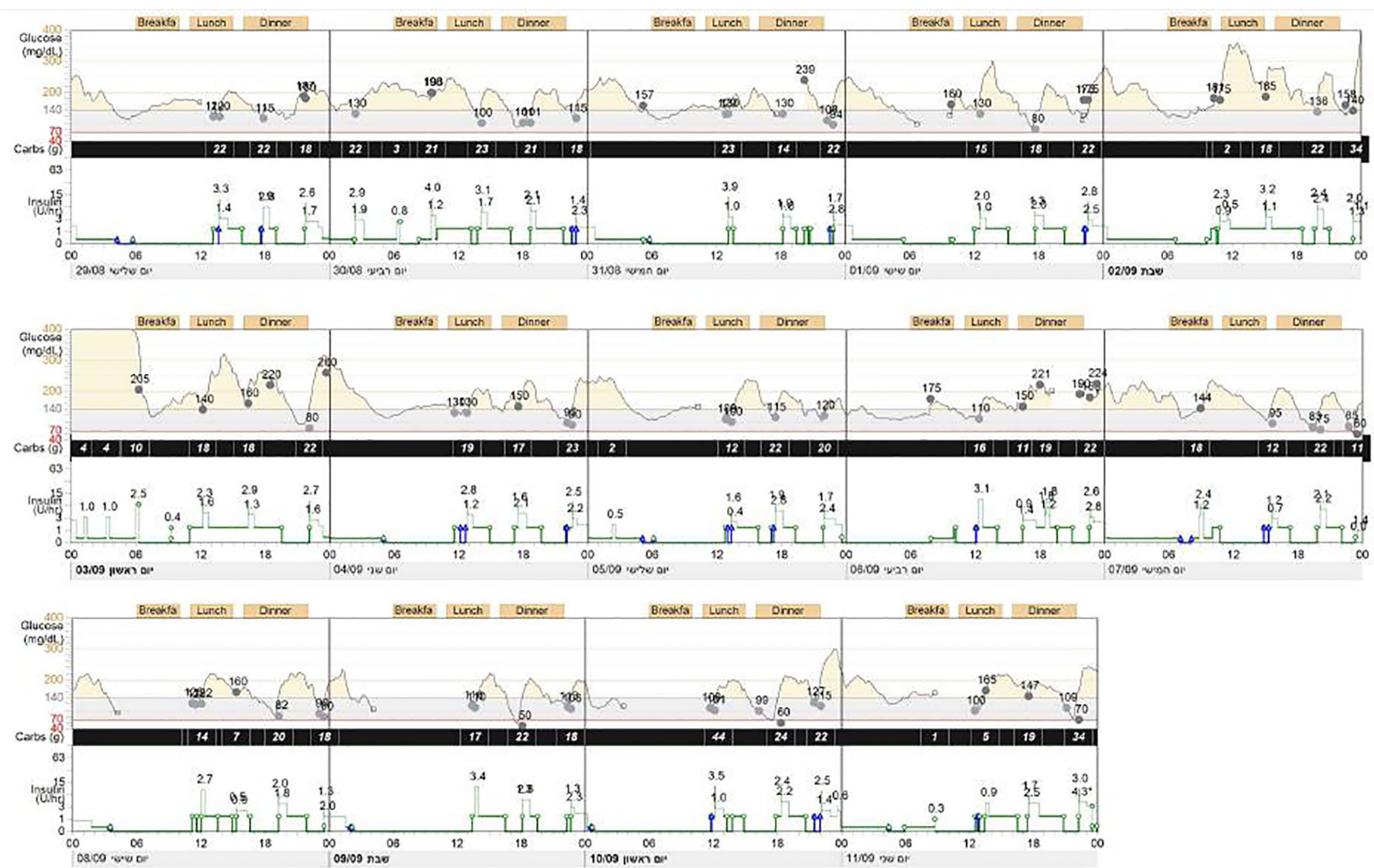

\begin{tabular}{|c|c|c|c|c|c|c|}
\hline$\sim$ Sensor trace & - $8 \mathrm{G}$ reading & - Basal & $\ldots$ Bolus & v Suspend & (1) Time change & - Exercise \\
\hline — Interrupted & $\nabla \Delta$ Off chart & ..... Temp basal & & $\begin{array}{l}\text { Suspend On Low } \\
\text { Suspend Before Lo }\end{array}$ & Injected insulin (U) & 口 Other \\
\hline
\end{tabular}


TABLE 1 | Auxologic, biochemical and imaging findings in the twins.

\begin{tabular}{|c|c|c|c|c|c|c|}
\hline & & \multicolumn{2}{|c|}{ At presentation } & \multicolumn{2}{|c|}{ Age 3 years } & \multirow{2}{*}{$\begin{array}{l}\text { Normal } \\
\text { values }\end{array}$} \\
\hline & & Twin 1 & Twin 2 & Twin 1 & Twin 2 & \\
\hline \multirow[t]{2}{*}{ Auxology } & Weight (kg) (SDS) & $1.98(-2.53)$ & $1.6(-3.5)$ & 14.35 & 16.6 & \\
\hline & Length (cm) (SDS) & ND & ND & 98.0 & 98.6 & \\
\hline \multirow{9}{*}{$\begin{array}{l}\text { Biochemical } \\
\text { results }\end{array}$} & Insulin $(\mu \mid \cup / m L)$ & $<0.2$ & $<0.2$ & ND & ND & $5-29.1$ \\
\hline & C -peptide (ng/ml) & 0.1 & 0.1 & 0.31 & 0.32 & $0.9-7.1$ \\
\hline & Insulin Abs (\%)* & Negative & Negative & & & $<7.0$ \\
\hline & GAD2 Abs $(\mathrm{U} / \mathrm{mL})^{\star}$ & Negative & 7.2 & & & $<1.0$ \\
\hline & IA2 Abs $(U / m L)^{\star}$ & Negative & Negative & & & $<0.75$ \\
\hline & $\mathrm{HbA1C}(\%)$ & 8.2 & 7.4 & 6.5 & 7.0 & $<5.6$ \\
\hline & TSH (mIU/L) & $>150$ & $>150$ & 2.52 & 24.5 & $0.64-6.27$ \\
\hline & FT4 (pmol/L) & $<1.3$ & 1.84 & 19.3 & 17.6 & $11.4-20.9$ \\
\hline & FT3 (pmol/L) & 1.99 & & 8.1 & & 3.5-6.5 \\
\hline \multirow[t]{4}{*}{ Imaging } & Abdominal US & ND & Normal & Normal & Normal & \\
\hline & $\begin{array}{l}\text { Kidney US with a } 4 \\
\text { mm cyst. }\end{array}$ & $\begin{array}{l}\text { Echogenic kidneys with small } \\
\text { cortical cysts }\end{array}$ & $\begin{array}{l}\text { Echogenic kidneys with small } \\
\text { cortical cysts }\end{array}$ & $\begin{array}{l}\text { Echogenic left kidney with a } \\
\qquad 4 \mathrm{~mm} \text { cyst. }\end{array}$ & Normal & \\
\hline & Thyroid US & & & Normal size and location & $\begin{array}{l}\text { Normal size and } \\
\text { location }\end{array}$ & \\
\hline & Brain MRI & & & Normal & Normal & \\
\hline
\end{tabular}

ND, not done, US, ultrasound.

${ }^{*}$ Pancreatic antibodies were collected at 23 days.

insufficiency (basal cortisol of $2.09 \mu \mathrm{g} / \mathrm{dL}$ and peak cortisol at $60 \mathrm{~min}$ of $32.86 \mu \mathrm{g} / \mathrm{dL}$; normal range $>20$ ).

At his last follow-up at the age of 3 years, his weight was $14.4 \mathrm{~kg}\left(40^{\text {th }}\right.$ centile $)$ and his height was $98 \mathrm{~cm}\left(60^{\text {th }}\right.$ centile $)$. His diabetes was well-managed ( $\mathrm{HbA1C}$ was $6.5 \%$ ) by CSII using Humalog diluted 1:10 $(10 \mathrm{U} / \mathrm{mL})$, with an insulin requirement of 0.7 unit/kg per day.

Auditory brainstem responses at 2 months of age revealed mild hearing impairment, but repeat examination at the age of 1 year was normal. Brain magnetic resonance imaging revealed no anomalies. He currently has mild global developmental delay and requires speech, physical and occupational therapy. He attends a kindergarten suited for children with special needs.

\section{Case 2}

The proband's twin sister was born weighing $1616 \mathrm{~g}$ (-3.5 SDS). Her birth, NICU hospitalization, and subsequent medical course were similar to that of her twin brother, with high blood glucose in the first $24 \mathrm{~h}$ (range 66-329 mg/dL). She was diagnosed with NDM, primary $\mathrm{CH}$, and CG. Treatment with a CSII pump (MiniMed 640G SmartGuard system) was initiated at 16 days of age, when she weighed $1730 \mathrm{~g}$. The management of her diabetes was similar to that of her brother's with recurrent episodes of hypoglycemia even after a few hours of insulin withdrawal.

She had elevated GOT, $136 \mathrm{U} / \mathrm{L}$, and total bilirubin was 8.04 $\mathrm{mg} / \mathrm{dL}$ with $3.9 \mathrm{mg} / \mathrm{dL}$ direct bilirubin. Abdominal ultrasound was normal

Laboratory evaluation at presentation revealed low insulin and C-peptide. She had positive glutamic acid decarboxylase (GAD) antibodies of $7.2 \mathrm{U} / \mathrm{mL}$ (normal range $<1$ ) and negative anti-insulin and anti-islet cell antibodies at 23 days (Table 1). She was hospitalized at 4 months of age due to pneumonia, and again at 9 months due to a viral illness. During the hospitalizations, her insulin requirements increased 3- to 4-fold. Due to persistent tachypnea, she underwent echocardiography that revealed a normal heart. She was diagnosed with reactive airway disease and was treated with a corticosteroid inhaler (fluticasone propionate $125 \mu \mathrm{g}$ twice daily). At her last follow-up at the age of 3 years, her weight was $16.6 \mathrm{~kg}\left(85^{\text {th }}\right.$ centile) and height was $98.6 \mathrm{~cm}$ ( $75^{\text {th }}$ centile). Her diabetes was well managed (HbA1C of 7.0\%) by CSII using Humalog diluted 1:10 (10 $\mathrm{U} / \mathrm{mL}$ ) with an insulin requirement of $0.9 \mathrm{unit} / \mathrm{kg}$ per day and with CGM. She currently has a mild to moderate delay in global development that requires speech, physical, and occupational therapy. She also attends a kindergarten suited for children with special needs.

\section{Molecular Analysis}

The combination of NDM with CH, IUGR and CG raised suspicion of a mutation in GLIS3. Analysis of all coding regions and exon/ intron boundaries of the GLIS3 gene (transcript NM_001042413.1) was performed by PCR amplification (primer sequences available on request) followed by Sanger sequencing. Sequencing reactions were performed in an ABI3730 capillary machine (Applied Biosystems) and analyzed using Mutation Surveyor (SoftGenetics). A novel homozygous nonsense mutation located in exon 9, c.2392C $>\mathrm{T}$, p.Gln798Ter (p.Q798*), was identified in both twins. The mutation introduces an early stop codon and is predicted to result in mRNA transcript degradation through nonsense-mediated decay. The genetic diagnosis was provided when the twins were 5 weeks of age. The parents are heterozygous carriers for the mutation. Another healthy sibling, born 1 year after the twins, was found through prenatal amniocentesis to be a heterozygous carrier of the same mutation.

\section{DISCUSSION}

We describe non-identical twins who are homozygous for a novel GLIS3 mutation, presenting with NDM, CH, CG, kidney cysts and 
TABLE 2 | Clinical and molecular findings of previous reported cases with GLIS3 mutations.

\begin{tabular}{|c|c|c|c|c|c|c|c|c|c|c|c|c|c|}
\hline No. & $M / F$ & Consanguinity & Origin & $\begin{array}{l}\text { B.W } \\
\text { (kg) }\end{array}$ & NDM & Pancreas & Hypothyroidism & Eye & Kidney & Liver & $\begin{array}{l}\text { Additional } \\
\text { features }\end{array}$ & Mutation Type & References \\
\hline $1^{a}$ & $\mathrm{~F}$ & Yes & Saudi- Arabia & 2.2 & $2 d$ & Small & Yes & No & $\begin{array}{l}\text { Multiple small } \\
\text { cysts }\end{array}$ & $\begin{array}{l}\text { Fibrosis and canalicular } \\
\text { cholestasis }\end{array}$ & Dysmorphism & $\begin{array}{l}\text { c.2067insC } \\
\text { (p.625fs703stop) }\end{array}$ & $(17,18)$ \\
\hline $2^{a}$ & M & Yes & Saudi- Arabia & 1.5 & $7 d$ & Not visualized & Yes & $C G$ & $\begin{array}{l}\text { Multiple small } \\
\text { cysts }\end{array}$ & $\begin{array}{l}\text { Fibrosis and canalicular } \\
\text { cholestasis }\end{array}$ & Dysmorphism & $\begin{array}{l}\text { c.2067insC } \\
\text { (p.625fs703stop) }\end{array}$ & $(17,18)$ \\
\hline $3^{a}$ & M & Yes & Saudi- Arabia & 1.4 & $7 d$ & NA & Yes & $C G$ & No & Hepatomegaly & Dysmorphism & $\begin{array}{l}\text { c.2067insC } \\
\text { (p.625fs703stop) }\end{array}$ & $(17,18)$ \\
\hline 4 & $\mathrm{~F}$ & Yes & Saudi- Arabia & 1.64 & Yes & $\begin{array}{l}\text { Hypoplastic } \\
\text { pancreas }\end{array}$ & $\begin{array}{l}\text { Yes } \\
\text { Agenesis }\end{array}$ & $C G$ & No & Hepatomegaly & Dysmorphism & $\begin{array}{l}426 \mathrm{~kb}-\mathrm{del} / \\
426 \mathrm{~kb}-\mathrm{del}\end{array}$ & $(17,18)$ \\
\hline $5^{\mathrm{b}}$ & M & Yes & France & 1.9 & Yes & NA & $\begin{array}{l}\text { Yes } \\
\text { No uptake }\end{array}$ & No & No & No & $\begin{array}{l}\text { Dysmorphism } \\
\text { MR }\end{array}$ & $\begin{array}{l}149 \mathrm{~kb}-\text { del/ } \\
149 \mathrm{~kb}-\mathrm{del}\end{array}$ & $(17,18)$ \\
\hline $6^{b}$ & M & Yes & France & 1.8 & Yes & Small & $\begin{array}{l}\text { Yes } \\
\text { Hypoplastic }\end{array}$ & No & No & Moderate steatosis & $\begin{array}{l}\text { Dysmorphism } \\
\text { MR }\end{array}$ & $\begin{array}{l}149 \mathrm{~kb}-\mathrm{del} / \\
149 \mathrm{~kb}-\mathrm{del}\end{array}$ & $(17,18)$ \\
\hline 7 & $\mathrm{~F}$ & Yes & Bangladeshi & 1.17 & $3 d$ & NA & $\begin{array}{l}\text { Yes } \\
\text { (Normal) } \\
\text { TSH resistance }\end{array}$ & No & $\begin{array}{l}\text { Cystic } \\
\text { dysplasia }\end{array}$ & Cirrhosis & $\begin{array}{l}\text { Exocrine } \\
\text { insufficiency, } \\
\text { Osteopenia }\end{array}$ & $\begin{array}{l}\text { Exons 1-2 del/ } \\
\text { Exons 1-2 del }\end{array}$ & $(20,21)$ \\
\hline $8^{c}$ & M & No & Welsh & 1.43 & $4 d$ & $\begin{array}{l}\text { Cystic change in } \\
\text { the } \\
\text { head of the } \\
\text { pancreas }\end{array}$ & $\begin{array}{l}\text { Yes } \\
\text { (Normal) } \\
\text { TSH resistance }\end{array}$ & No & $\begin{array}{l}\text { Cystic } \\
\text { dysplasia }\end{array}$ & $\begin{array}{l}\text { Moderate parenchymal } \\
\text { cholestasis }\end{array}$ & $\begin{array}{l}\text { Exocrine } \\
\text { insufficiency, } \\
\text { Sensorineural } \\
\text { deafness }\end{array}$ & $\begin{array}{l}\text { Exons 1-4 del/ } \\
\text { Exons 1-4 del }\end{array}$ & $(20,21)$ \\
\hline $9^{c}$ & M & No & Welsh & 2.02 & $2 d$ & NA & Yes & No & Renal cysts & Yes & $\begin{array}{l}\text { Exocrine } \\
\text { insufficiency }\end{array}$ & $\begin{array}{l}\text { Exons 1-4 del/ } \\
\text { Exons 1-4 del }\end{array}$ & (21) \\
\hline 10 & $\mathrm{~F}$ & No & Caucasian & 2.75 & $2 d$ & NA & No & No & No & No & Choanal atresia & $\begin{array}{l}\text { c.1765C>T } \\
\text { p.Arg589Trp/Exons 1- } \\
11 \mathrm{del}\end{array}$ & (21) \\
\hline 11 & $\mathrm{~F}$ & Yes & Arab & 1.75 & $2 d$ & NA & $\begin{array}{l}\text { Yes } \\
\text { (Agenesis) }\end{array}$ & No & $\begin{array}{l}\text { Cystic } \\
\text { dysplasia }\end{array}$ & Hepatitis & No & $\begin{array}{l}\text { Exons 5-9 del/ } \\
\text { Exons 5-9 del }\end{array}$ & $(4,21)$ \\
\hline 12 & M & Yes & Arab & 2.05 & $5 d$ & NA & Yes & No & No & No & Skeletal anomalies & $\begin{array}{l}\text { c. } 1608 \mathrm{C}>\mathrm{G} \\
\text { p.Cys536Trp/ } \\
\text { Cys593Trp }\end{array}$ & $(4,21)$ \\
\hline 13 & $\mathrm{~F}$ & NA & $\begin{array}{l}\text { African- } \\
\text { American }\end{array}$ & 1.53 & $7 d$ & NA & $\begin{array}{l}\text { Yes } \\
\text { (Normal) }\end{array}$ & $C G$ & Renal cysts & Cirrhosis & $\begin{array}{l}\text { Sagittal } \\
\text { craniosynostosis }\end{array}$ & $\begin{array}{l}\text { Exons 9-11 del/ } \\
\text { Exons 9-11 del }\end{array}$ & (21) \\
\hline 14 & $\mathrm{~F}$ & Yes & Yemeni & 1.23 & $3 d$ & NA & $\begin{array}{l}\text { Yes } \\
\text { (Normal) }\end{array}$ & $C G$ & Renal cysts & Hepatic fibrosis & $\begin{array}{l}\text { Exocrine } \\
\text { insufficiency }\end{array}$ & $\begin{array}{l}\text { Exons } 10-11 \mathrm{del} / \\
\text { Exons } 10-11 \mathrm{del}\end{array}$ & (21) \\
\hline 15 & $\mathrm{~F}$ & Yes & Pakistani & 1.86 & $1 d$ & NA & Yes & No & Renal cysts & No & $\begin{array}{l}\text { Sensorineural } \\
\text { deafness }\end{array}$ & $\begin{array}{l}\text { c.932delG } \\
\text { p.Gls311Alafs/ } \\
\text { Gls311Alafs }\end{array}$ & (21) \\
\hline 16 & M & Yes & Turkish & 1.52 & $21 d$ & NA & Yes & No & Renal cysts & Hepatic fibrosis & No & $\begin{array}{l}\text { Exons 3-4 del/ } \\
\text { Exons 3-4 del }\end{array}$ & (21) \\
\hline 17 & M & Yes & Kurdish & 0.97 & $31 d$ & NA & $\begin{array}{l}\text { Yes } \\
\text { (Normal) }\end{array}$ & $C G$ & Renal cysts & Hepatic fibrosis & PDA & $\begin{array}{l}\text { c. } 1681 C>T \\
\text { p.His561Tyr/ } \\
\text { His561Try }\end{array}$ & (21) \\
\hline 18 & M & Yes & Arab & 1.7 & $19 d$ & NA & Yes & $C G$ & Renal cysts & No & ASD & $\begin{array}{l}\text { Exons } 1-2 \mathrm{del} / \\
\text { Exons } 1-2 \mathrm{del}\end{array}$ & (21) \\
\hline 19 & M & Yes & Saudi-Arabia & 1.3 & $2 d$ & NA & Yes & $C G$ & No & No & No & $\begin{array}{l}\text { c.2312_2314dupTC } \\
\text { p.Pro722Leufs }{ }^{\star} 35 / \\
\text { Pro722Leufs }{ }^{\star} 35\end{array}$ & (22) \\
\hline
\end{tabular}


developmental delay. The management of their diabetes was challenging due to recurrent hypoglycemic episodes.

Since the first description in 2006 of GLIS3 mutations causing a syndromic form of NDM in three siblings of a consanguineous family from Saudi Arabia $(17,18)$, an additional 16 patients have been reported carrying 14 different mutations (Table 2) (17, 19-23). All patients had NDM presenting between 1 and 31 days of life.

The molecular etiologies of NDM can be divided into three broad groups according to the defect that they cause in pancreatic function: abnormal $\beta$-cell function (KCNJ11, ABCC8, INS, GCK, SLC2A2, SLC19A2), $\beta$-cell destruction (dominant INS, EIF2AK3, IER3IPI, FOXP3, WFS1, EIF2B1, LRBA) and abnormal pancreatic development (PDX1, PTF1A, HNF1B, RFX6, GATA4, GATA6, NEUROG3, NEUROD1, NKX2-2, MNX1, RFX6, CNOT1) (6). The GLIS3 gene is involved in the development of pancreatic $\beta$-cells and as such, belongs to the third group. In particular, in-vivo studies using Glis3-knockout mice have shown that Glis3 plays a critical role in cell-lineage differentiation, particularly in the development of $\beta$-cells, in the regulation of mature $\beta$-cell function and survival, and in insulin regulation (15).

In most patients with GLIS3 mutations reported to date, and as was noted in our patients, a normal-size pancreas is observed. However, pancreatic hypoplasia and exocrine pancreatic insufficiency requiring pancreatic enzyme replacement and nutrient supplementation have been reported in some patients (21), but not in our cases. These findings support a possible role of GLIS3 in exocrine pancreatic development, as well as in $\beta$ cell development.

Patients with GLIS3 mutations do not typically show any evidence of autoimmune markers, in contrast to type 1 diabetes mellitus in which the autoimmune destruction of $\beta$-cells is usually associated with the presence of pancreatic autoantibodies. Interestingly, anti-GAD antibodies were elevated in case 2. Although the presence of anti-GAD antibodies has been reported in rare cases of patients with non-autoimmune NDM (23), it would be interesting to investigate whether other patients with homozygous GLIS3 mutations are positive for these antibodies. It would also be important to follow up our patient to determine whether she might revert to being GAD negative, as previously reported in some non-diabetic individuals (24). Of note, GLIS3 gene polymorphisms have been associated with risk of type 1 diabetes mellitus in genome-wide association studies $(25,26)$, indicating that GLIS3 is a susceptibility locus for this disease.

Both twins had intermittent episodes of hypoglycemia that resulted in insulin-pump disconnection. Moreover, in case 1, prolonged unresponsive hypoglycemia, resistant to glucagon therapy, was observed during an acute illness, requiring cessation of insulin therapy for 3 days. Other causes for hypoglycemia and adrenal insufficiency were excluded. Recurrent hypoglycemic episodes have been reported in one additional case with a GLIS3 mutation (21). The mechanism through which these patients develop hypoglycemia is currently unknown, and further studies are needed to investigate its causes. Hypoglycemic episodes in the first days of life in small for gestational age infants are attributed to low liver glycogen storage. However, in our cases, the hypoglycemic events occurred during follow-up when the probands were older and at normal weight for their age. One explanation could be that 
GLIS3 dysfunction directly affects the regulation of insulin secretion. Indeed, GLIS3 expression persists beyond the embryonic period, promoting $\beta$-cell proliferation and $\beta$-cell survival, and regulating insulin gene (INS) expression by binding to GLIS3-response element in the INS promoter $(16,27)$. GLIS3 has been shown to activate pancreatic and duodenal homeobox 1 (PDX1), as well as neurogenic differentiation 1 (NEUROD1) expression and potently controls INS transcription (27). It has been shown that mice lacking Glis3 have decreased numbers of glucagon-positive cells (28); however, the fact that no response to glucagon injections was observed in case 1 does not support low glucagon secretion as the cause for recurrent hypoglycemic episodes in these cases. Genomewide association studies have revealed that GLIS3 variants are associated with type 2 , as well as type 1 , diabetes mellitus (26), supporting its involvement in insulin sensitivity, which may explain the requirement of high insulin doses under stress conditions in our patients, as well as in other reports (20).

Our twins were homozygous for a novel nonsense mutation located in exon 9 (p.Q798*), which results in a premature stop codon. It is likely that the mutated transcript undergoes nonsense-mediated decay and little or no protein is produced. Five missense mutations of GLIS3 have been reported to date; another eight mutations were intragenic deletions, and one was a duplication resulting in a frameshift (Table 2). A rapid molecular diagnosis of NDM is recommended as the specific etiology assists in clinical management (insulin $v s$. sulfonylurea), and may also guide longitudinal monitoring for other associated problems in NDM subtypes with syndromic features, as well as for screening family members $(5,9)$. Indeed, in the family reported on here, prenatal genetic testing revealed heterozygosity for the same GLIS3 mutation in a later pregnancy.

Management of diabetes in our patients was challenging. The use of multiple insulin injections in infants results in labile blood glucose levels, and the use of NPH insulin commonly results in hypoglycemic episodes (5). Moreover, no insulin analogues are currently approved for use in infants ( $<1$ year). CSII has been shown to provide the most effective management of $\operatorname{NDM}(5,29$, 30). However, insulin dilution is required to prevent pump obstruction. In contrast, the usefulness of CGM in neonates is arguable, since inaccuracy of CGM in newborns may lead to more interventions with potentially adverse effects on outcomes (31). The combination of CSII and CGM enabled the family to maintain blood glucose in a safe range and to prevent severe hypoglycemic events due to the automatic insulin-delivery shutoff system when the CGM predicts hypoglycemic values.

\section{REFERENCES}

1. Iafusco D, Massa O, Pasquino B, Colombo C, Iughetti L, Bizzarri C, et al. Early Diabetes Study Group of ISPED. Minimal Incidence of Neonatal/Infancy Onset Diabetes in Italy is 1:90,000 Live Births. Acta Diabetol (2012) 49 (5):405-8. doi: 10.1007/s00592-011-0331-8

2. Grulich-Henn J, Wagner V, Thon A, Schober E, Marg W, Kapellen TM, et al. Entities and Frequency of Neonatal Diabetes: Data From the Diabetes Documentation and Quality Management System (Dpv). Diabetes Med (2010) 27(6):709-12. doi: 10.1111/j.1464-5491.2010.02965.x

3. Deeb A, Habeb A, Kaplan W, Attia S, Hadi S, Osman A, et al. Genetic Characteristics, Clinical Spectrum, and Incidence of Neonatal Diabetes in the

\section{CONCLUSIONS}

We report a novel GLIS3 mutation in non-identical twins, further characterizing the genotypic and phenotypic spectra in individuals with this rare genetic condition. Defining the clinical features of patients with rare forms of NDM is fundamental to providing insights into the roles of genes such as GLIS3 in the pathophysiology of diabetes mellitus.

\section{DATA AVAILABILITY STATEMENT}

The raw data supporting the conclusions of this article will be made available by the authors, without undue reservation.

\section{ETHICS STATEMENT}

The patients' parents gave written informed consent for the publication of this case report.

\section{AUTHOR CONTRIBUTIONS}

SL, GE-A, MB, CF, MP, SW, and YT-R analyzed and interpreted the clinical and biochemical aspects of the patients' data. EF analyzed and interpreted the molecular genetic data. SL, EF, SW, and YT-R contributed to writing the manuscript. All authors contributed to the article and approved the submitted version.

\section{ACKNOWLEDGMENTS}

Genetic testing was provided by the Exeter Genomics Laboratory and funded by a Wellcome Trust Senior Investigator grant to Professor Sian Ellard and Professor Andrew Hattersley. EF is a Diabetes UK RD Lawrence Fellow in diabetes research. We thank Camille Vainstein for professional English editing and the parents for kind collaboration. Thanks Tali Bessor for closely accompanying and for education of the family how to use insulin pump.

Emirate of AbuDhabi, United Arab Emirates. Am J Med Genet A (2016) 170 (3):602-9. doi: 10.1002/ajmg.a.37419

4. Habeb AM, Al-Magamsi MS, Eid IM, Ali MI, Hattersley AT, Hussain K, et al. Incidence, Genetics, and Clinical Phenotype of Permanent Neonatal Diabetes Mellitus in Northwest Saudi Arabia. Pediatr Diabetes (2012) 13(6):499-505. doi: 10.1111/j.1399-5448.2011.00828.x

5. Lemelman MB, Letourneau L, Greeley SAW. Neonatal Diabetes Mellitus: An Update on Diagnosis and Management. Clin Perinatol (2018) 45(1):41-59. doi: $10.1016 /$ j.clp.2017.10.006

6. Rubio-Cabezas O, Ellard S. Diabetes Mellitus in Neonates and Infants: Genetic Heterogeneity, Clinical Approach to Diagnosis, and Therapeutic Options. Horm Res Paediatr (2013) 80(3):137-46. doi: 10.1159/000354219 
7. De Franco E, Ellard S. Genome, Exome, and Targeted Next-Generation Sequencing in Neonatal Diabetes. Pediatr Clin North Am (2015) 62 (4):1037-53. doi: 10.1016/j.pcl.2015.04.012

8. De León DD, Stanley CA. Permanent Neonatal Diabetes Mellitus (2008). GeneReviews. Available at: https://www.ncbi.nlm.nih.gov/books/NBK1447/ (Accessed February, 27, 2021).

9. De Franco E, Flanagan SE, Houghton JA, Lango Allen H, Mackay DJ, Temple IK, et al. The Effect of Early, Comprehensive Genomic Testing on Clinical Care in Neonatal Diabetes: An International Cohort Study. Lancet (2015) 386 (9997):957-63. doi: 10.1016/S0140-6736(15)60098-8

10. Pinto K, Chetty R. Gene of the Month: Glis1-3. J Clin Pathol (2020) 73(9):52730. doi: 10.1136/jclinpath-2020-206859

11. Dimitri P. The Role of GLIS3 in Thyroid Disease as Part of a Multisystem Disorder. Best Pract Res Clin Endocrinol Metab (2017) 31(2):175-82. doi: 10.1016/j.beem.2017.04.007

12. Kang HS, Kim YS, ZeRuth G, Beak JY, Gerrish K, Kilic G, et al. Transcription Factor Glis3, a Novel Critical Player in the Regulation of Pancreatic Beta-Cell Development and Insulin Gene Expression. Mol Cell Biol (2009) 29(24):636679. doi: 10.1128/MCB.01259-09

13. Kang HS, ZeRuth G, Lichti-Kaiser K, Vasanth S, Yin Z, Kim YS, et al. GliSimilar (Glis) Krüppel-Like Zinc Finger Proteins: Insights Into Their Physiological Functions and Critical Roles in Neonatal Diabetes and Cystic Renal Disease. Histol Histopathol (2010) 25(11):1481-96. doi: 10.14670/HH25.1481

14. Kang HS, Beak JY, Kim YS, Herbert R, Jetten AM. Glis3 Is Associated With Primary Cilia and Wwtr1/TAZ and Implicated in Polycystic Kidney Disease. Mol Cell Biol (2009) 29(10):2556-69. doi: 10.1128/MCB.01620-08

15. Kim YS, Nakanishi G, Lewandoski M, Jetten AM. GLIS3, a Novel Member of the GLIS Subfamily of Krüppel-Like Zinc Finger Proteins With Repressor and Activation Functions. Nucleic Acids Res (2003) 31(19):5513-25. doi: 10.1093/ nar/gkg776

16. Beak JY, Kang HS, Kim YS, Jetten AM. Functional Analysis of the Zinc Finger and Activation Domains of Glis3 and Mutant Glis3 (Ndh1). Nucleic Acids Res (2008) 36(5):1690-702. doi: 10.1093/nar/gkn009

17. Senée V, Chelala C, Duchatelet S, Feng D, Blanc H, Cossec JC, et al. Mutations in GLIS3 are Responsible for a Rare Syndrome With Neonatal Diabetes Mellitus and Congenital Hypothyroidism. Nat Genet (2006) 38(6):682-7. doi: $10.1038 /$ ng 1802

18. Taha D, Barbar M, Kanaan H, Williamson Balfe J. Neonatal Diabetes Mellitus, Congenital Hypothyroidism, Hepatic Fibrosis, Polycystic Kidneys, and Congenital Glaucoma: A New Autosomal Recessive Syndrome? Am J Med Genet A (2003) 122A(3):269-73. doi: 10.1002/ajmg.a.20267

19. Dimitri P, De Franco E, Habeb AM, Gurbuz F, Moussa K, Taha D, et al. An Emerging, Recognizable Facial Phenotype in Association With Mutations in GLI-Similar 3 (Glis3). Am J Med Genet A (2016) 170(7):1918-23. doi: 10.1002/ajmg.a.37680

20. Dimitri P, Warner JT, Minton JA, Patch AM, Ellard S, Hattersley AT, et al. Novel GLIS3 Mutations Demonstrate an Extended Multisystem Phenotype. Eur J Endocrinol (2011) 164(3):437-43. doi: 10.1530/EJE-10-0893
21. Dimitri P, Habeb AM, Gurbuz F, Millward A, Wallis S, Moussa K, et al. Expanding the Clinical Spectrum Associated With GLIS3 Mutations. J Clin Endocrinol Metab (2015) 100(10):E1362-9. doi: 10.1210/jc.2015-1827

22. Alghamdi KA, Alsaedi AB, Aljasser A, Altawil A, Kamal NM. Extended Clinical Features Associated With Novel Glis3 Mutation: A Case Report. BMC Endocr Disord (2017) 17(1):14. doi: 10.1186/s12902-017-0160-Z

23. Johnson MB, Patel KA, Franco ED, Hagopian W, Killian M, McDonald TJ, et al. Type 1 Diabetes can Present Before the Age of 6 Months and Is Characterised by Autoimmunity and Rapid Loss of Beta Cells. Diabetologia (2020) 63(12):2605-15. doi: 10.1007/s00125-020-05276-4

24. Sørgjerd EP, Thorsby PM, Torjesen PA, Skorpen F, Kvaløy K, Grill V. Presence of Anti-GAD in a Non-Diabetic Population of Adults; Time Dynamics and Clinical Influence: Results From the HUNT Study. BMJ Open Diabetes Res Care (2015) 3(1):e000076. doi: 10.1136/bmjdrc-2014000076

25. Wen X, Yang Y. Emerging Roles of GLIS3 in Neonatal Diabetes, Type 1 and Type 2 Diabetes. J Mol Endocrinol (2017) 58(2):R73-85. doi: 10.1530/JME-16-0232

26. Yang Y, Chan L. Monogenic Diabetes: What It Teaches Us on the Common Forms of Type 1 and Type 2 Diabetes. Endocr Rev (2016) 37(3):190-222. doi: 10.1210/er.2015-1116

27. Yang Y, Hung-Junn Chang B, Samson SL, Li MV, Chan L. The Krüppel-Like Zinc Finger Protein Glis3 Directly and Indirectly Activates Insulin Gene Transcription. Nucleic Acids Res (2009) 37(8):2529-38. doi: 10.1093/nar/gkp122

28. Watanabe N, Hiramatsu K, Miyamoto R, Yasuda K, Suzuki N, Oshima N, et al. A Murine Model of Neonatal Diabetes Mellitus in Glis3-Deficient Mice. FEBS Lett (2009) 583(12):2108-13. doi: 10.1016/j.febslet.2009.05.039

29. Rabbone I, Barbetti F, Marigliano M, Bonfanti R, Piccinno E, Ortolani F, et al. Successful Treatment of Young Infants Presenting Neonatal Diabetes Mellitus With Continuous Subcutaneous Insulin Infusion Before Genetic Diagnosis. Acta Diabetol (2016) 53(4):559-65. doi: 10.1007/s00592-015-0828-7

30. Ortolani F, Piccinno E, Grasso V, Papadia F, Panzeca R, Cortese C, et al. Diabetes Associated With Dominant Insulin Gene Mutations: Outcome of 24Month, Sensor-Augmented Insulin Pump Treatment. Acta Diabetol (2016) 53 (3):499-501. doi: 10.1007/s00592-015-0793-1

31. Shah R, McKinlay CJD, Harding JE. Neonatal Hypoglycemia: Continuous Glucose Monitoring. Curr Opin Pediatr (2018) 30(2):204-8. doi: 10.1097/ MOP.0000000000000592

Conflict of Interest: The authors declare that the research was conducted in the absence of any commercial or financial relationships that could be construed as a potential conflict of interest.

Copyright (๑) 2021 London, De Franco, Elias-Assad, Barhoum, Felszer, Paniakov, Weiner and Tenenbaum-Rakover. This is an open-access article distributed under the terms of the Creative Commons Attribution License (CC BY). The use, distribution or reproduction in other forums is permitted, provided the original author(s) and the copyright owner(s) are credited and that the original publication in this journal is cited, in accordance with accepted academic practice. No use, distribution or reproduction is permitted which does not comply with these terms. 